\title{
A DUÁLIS KÉPZÉSI PROGRAMOK FEJLESZTÉSÉNEK MÓDSZERTANI ÉS OKTATÁSSZERVEZÉSI KÉRDÉSEI
}

\section{METHODOLOGICAL AND ORGANIZATIONAL QUESTIONS OF DEVELOPING DUAL EDUCATIONAL PROGRAMS}

\author{
Szigeti Ferenc ${ }^{1}$, Dezső Gergely ${ }^{2}$, Kósa Péter $^{3}$ \\ Nyíregyházi Egyetem, Müszaki és Agrártudományi Intézet, Müszaki Alapozó, Fizika \\ és Gépgyártástechnológia Tanszék, H-4553, Magyarország, Nyíregyháza, Sóstói út \\ 31/b,+3642599400/+3642312825, ${ }^{1}$ szigetif@nyf.hu, ${ }^{2}$ dezsog@nyf.hu
}

\begin{abstract}
Introducing dual education to higher education requires not only ensuring legal background, providing financial resources and cooperation with members of industrial sector, but developing training programs corresponding to conditions of the new form of education. This means tasks on content and form of education, and pedagogical methodology. The whole process must be reconsidered, because new priorities arised in objectives and new participants attended to the education. Both international and inland experiences show that lack of eligible considering and plan of dual education cause problems what can be avoided today. In this paper we present main methodological and pedagogical organizational challenges solved during introduction of dual education at University of Nyíregyháza. Dual education in mechanical engineering has been started since September of 2015, and established in other programs at University of Nyíregyháza.
\end{abstract}

Keywords: dual education, higher education, training program

\section{Összefoglalás}

A duális képzések megszervezése a felsőoktatásban megkívánja a jogszabályi háttér megalkotásán, a pénzügyi feltételek biztosításán, a versenyszféra szereplőivel való megegyezésen túl olyan képzési programok kifejlesztését, amelyek megfelelnek az új típusú képzési forma feltételeinek. Ez tartalmi, oktatásszervezési és pedagógiai módszertani feladatokat is jelent. Tekintettel arra, hogy a képzési folyamat célrendszerében új prioritások jelennek meg, és arra, hogy a tanítási-tanulási folyamatban új szereplők vállalnak feladatokat, alapjaitól kell átgondolni azt. Nemcsak külföldi, de már magyarországi tapasztalatok is megerősítik, hogy a nem kellő körültekintéssel felépített duális képzés számos olyan nehézséget okoz minden résztvevőjének, amelyek ma már elkerülhetők. Dolgozatunkban bemutatjuk a Nyíregyházi Főiskolán elindított duális képzések bevezetése során megoldott, a képzési program fejlesztésével kapcsolatos föbb módszertani és oktatásszervezési kérdéseket. 2015 szeptemberétől a gépészmérnök szakon indult, a következő tanévtől pedig több más szakon is indul duális képzés a Nyíregyházi Főiskolán.

Kulcsszavak: duális képzés, felsőoktatás, képzési program 


\section{Bevezetés}

A magyarországi Duális Képzési Tanács meghatározása szerint ,a gyakorlatigényes alapképzési szakon folytatott képzés azon formája, amelyben a szakmailag minősített vállalatoknál folyó gyakorlati képzések tantervi tartalmuknál, struktúrájuknál és a vállalatoknál töltendő, megnövelt óraszámuknál, valamint a megszerzett munkatapasztalatnál fogva növelik a hallgatók szakmai kompetenciáját, vállalati ismereteit és erősítik a kultúráját, mivel a duális képzés esetében a közremüködő vállalat elöre meghatározott módon a felsőoktatási intézmény tananyagához szorosan illeszkedve, formálisan is oktatja a hallgatókat a képzés során" [1]. Jellemző a duális képzésre, hogy a felsőoktatási intézményben oktatott elméleti és a vállalatnál oktatott gyakorlati képzés között kapcsolatnak kell lennie. A vállalatnál megvalósított gyakorlat fő jellemzői a specifikus ismeretek elsajátítása, a hallgató bevonása az üzemi gyakorlatba, projektfeladatokba, továbbá az ún. puha (soft) készségek elsajátítására biztosított lehetőség.

A felsőoktatási intézmények és a gazdaság szereplői által megvalósított kooperatív képzések csoportosíthatók az oktatásban történő szerepvállalás és együttmüködés mélysége szerint [2]. Az ún. együttmüködésen alapuló kooperáció az oktatásnak csak részterületeit érinti, nem feltételez intézményesített együttmüködést, esetleges is lehet. A képzést támogató kooperáció szintjén a képzés helyszíne továbbra is a felsőoktatási intézmény, de a vállalat eszközökkel és szakmai anyagokkal rendszeresen támogatja azt, esetenként a magasabb szintü támogatásért cserébe csekély mértékben beleszólást nyer a szakmai munkába. Az opcionális duális képzési modellben a felsőoktatási intézmény hallgatóinak egy része olyan képzésben vesz részt, amelyet az intézmény egy vállalattal közösen tervez és valósít meg. A hallgatók másik része azonban nem vesz részt a duális képzésben, számukra a felsőoktatási intézmény továbbra is biztosítja a hagyományos képzést. Ebbe a kategóriába tartozik a Nyíregyházi Főiskolán elindított duális képzés is. Ismert a duális képzés hálózatos modellje, amely bizonyos körülmények között jó alternatíva, és sajátos jellemzői vannak a többi módszerrel szemben. A kooperáció legmélyebb formája az integrált duális képzés, amely a vállalatok és a felsőoktatás között úgy osztja meg a feladatokat, hogy a hagyományos képzéshez képest a felsőoktatási intézmények teljes mértékben lemondanak bizonyos, a gyakorlati képzéshez kapcsolódó funkcióikról (például a hallgatói laborok müködtetéséről, számos eszközről, az azokhoz rendelt humán erőforrásról), mert azokat teljes mértékben a vállalatok biztosítják a képzés számára. Ebben a modellben minden hallgató részt vesz a duális képzésben. Nyilvánvaló, hogy az ilyen képzés megvalósítása átfogó gazdaság- és oktatáspolitikai megközelítést igényelne.

A Nyíregyházi Főiskolán elsőként, a 2015/2016-os tanévben a gépészmérnök szakon vezettük be a duális képzést. A következő tanévben újabb duális szakok indulnak müszaki és közgazdaságtudományi területeken [4].

Ebben a beszámolóban a gépészmérnök szak duálissá alakításának tapasztalatairól esik szó. A duális képzési program kifejlesztésének folyamatát mutatjuk be, különös tekintettel azokra a vonásokra, amelyek sajátosak a hagyományos képzéshez viszonyítva.

A sajátos vonások elsősorban a következő körülményekből adódnak:

- a képzést az föiskola egy vállalati partnerrel együtt valósítja meg;

- a képzési és kimeneti követelményrendszernek maradéktalanul teljesülnie kell a duális képzésben részt vevő hallgatók esetében is; 
- a hallgatók nemcsak az föiskolával, hanem a vállalattal is jogviszonyba kerülnek;

- a képzés során az elméleti és a gyakorlati tananyag tartalmának és időbeli ütemezésének is összhangban kell állnia.

A képzési program fejlesztése az opcionális duális képzési modellből adódóan elsősorban a vállalati képzési programok megalkotását jelenti, ugyanakkor ezenfelül számos egyéb feltételt is meg kellett teremteni a képzés megvalósíthatósága érdekében.

\section{A képzési program peremfelté- telei}

A magyarországi felsőoktatási itnézmények többségéhez hasonlóan a Nyíregyházi Főiskolára sem jellemző a böséges oktatói humánerőforrás-ellátottság, ezért arra törekedtünk, hogy a duális képzés bevezetése minimális oktatói erőforrást kössön le. Ezért is tartottuk célszerünek az ún. kecskeméti modell [3] adaptálását. Ebben a struktúrában az elméleti ismeretek elsajátítása a hagyományos képzésben részt vevő hallgatókkal együtt zajlik. Így a tantárgyi programok lényegében nem igényeltek változtatást.

A duális képzési program fejlesztésének súlypontja a vállalati képzési programok elkészítésén volt. Itt viszont több, egymást feltételező feladatot kellett megoldani párhuzamosan, viszonylag rövid idő alatt..

\section{A képzési program felépítésé- nek folyamata}

$\mathrm{Az}$ 1. ábra vázolja azt a folyamatot, amelyen érdemes végighaladni a duális képzés vállalati gyakorlati programjának felépítése során. Elképzelhetö, hogy a föiskolai oktatók vagy a vállalat munkatársai ezt túlzásnak érzik, de fontos tudni, hogy a képzés megvalósítási szakaszában már nincs lehetöség ilyen szintü és mélységü tervezésre. Ennek elmaradása akár félreér- tésekhez, konfliktusokhoz is vezethet, amelyek aláássák a duális képzés megfelelö megvalósítását.

A táblázat üzenete röviden így foglalható össze: jól meg kell ismernie egymást a képzést végző két képzőhelynek, és minél alaposabban át kell gondolniuk, kinek mi a feladata. Ezeket a feladatokat nem csupán maguk között egyeztetve alakítják ki, hanem jogszabályok, és az egymással, valamint a hallgatóval kötött szerződések is szabályozzák azokat. Ebben a vállalat vezetésének is komoly feladata van. Később, az operatív szakaszban a jól elkészített munkaterv esetén a vezetést már lényegében nem terheli a duális képzés.

$\mathrm{Az}$ 1. ábra első sorának harmadik oszlopában olvasható a témalista kifejezés. Ezt érdemes megmagyarázni. Olyan tevékenységek felsorolását jelenti, amelyek

- a vállalatnál önálló munkaegységként kezelhetők,

- nincs jogi akadálya a képzésbe való bevonásnak (pl. titoktartás, különösen veszélyes munkakör stb.),

- az főiskola oktatójával egyeztetve ráépíthető az föiskolai akadémiai képzésre.

A témalistában szereplö tételekre példák az alábbiak: műhelyrajz készítése, raktárban anyagok, alkatrészek kiválasztása, forgácsolási művelet elvégzése, hegesztési utasítás készítése (de a hegesztés elvégzése jellemzően nem tartozik ide, mert ahhoz megfelelő minősítés szükséges), villanymotor karbantartása, mérések elvégzése (kézi, müszeres, egyedi, sorozat, pl. hosszúság, felületi érdesség, keménység, mikroszkópos ellenőrzés stb.), prezentáció készítése egy projektről a vállalat vezetése számára, árajánlat készítése. Ezek a tevékenységek mind mentori felügyelet mellett zajlanak. A témalista az föiskolai oktatók üzembejárása, valamint a vállalat szakembereivel történő egyeztetések során alakul ki. Egyelöre nem rendezett. Ezek a „témák” lesznek a gyakorlati képzési program építőkövei. 


\subsection{Szakmai megalapozás}

A vállalatok és a föiskola szakembereinek kölcsönösen meg kellett ismerniük egymás szakmai tevékenységét, módszereit. Bár a duális képzéshez csatlakozó vállalatokkal volt előzetes szakmai kapcsolata az intézetünknek, az általában egy-egy speciális feladatra korlátozódott. A duális képzés szakmai megalapozásához azonban teljes áttekintést kellett kapniuk a föiskola oktatóinak a vállalatok szakmai munkájáról, a vállalatok szakembereinek pedig a föiskola képzési programjáról. Ezt szakmai kerekasztal beszélgetésekkel és üzemlátogatásokkal valósítottuk meg. Tapasztalatunk szerint ez egy idő- és emberierőforrásigényes feladat. Ezért nagyobb kihívást jelentett annál, ahogy azt eredetileg gondol- tuk. Ugyanakkor ez egy kritikus része a folyamatnak, enélkül nem lehet felépíteni a képzési programot.

\subsection{Az elmélet és a gyakorlat össze- hangolása}

A duális képzés fontos jellemzője a föiskolán zajló elméleti és a vállalatnál megvalósuló gyakorlati képzés összhangja. A hallgató nem kaphat olyan gyakorlati feladatot, amelyhez korábban az elméleti alapokat nem tanulta meg. Az elméleti alapozást a vállalat is elvégezhetné, de esetünkben erre nem volt kifejezett igény. Ezért a gyakorlati programot úgy építettük fel, hogy az akadémiai képzés időbeli ütemezését figyelembe véve gondosan összehangoltuk azzal a gyakorlat tevékenységeit.

\begin{tabular}{|l|l|l|l|}
\hline \multicolumn{1}{|c|}{ Cél } & \multicolumn{1}{|c|}{$\begin{array}{c}\text { Fóiskola } \\
\text { tevékenysége }\end{array}$} & \multicolumn{1}{c|}{$\begin{array}{c}\text { Vállalat } \\
\text { tevékenysége }\end{array}$} & \multicolumn{1}{c|}{ Kimenet } \\
\hline $\begin{array}{l}\text { A lehetséges } \\
\text { tevékenységek } \\
\text { beazonosítása } \\
\text { („,metszetek”) }\end{array}$ & $\begin{array}{l}\text { Beazonosítja a } \\
\text { tantárgyakhoz } \\
\text { köthető vállalati } \\
\text { tevékenységeket. } \\
\text { Látogatás és } \\
\text { konzultáció a } \\
\text { vállalatoknál. }\end{array}$ & $\begin{array}{l}\text { Beazonosítja a } \\
\text { duális képzésbe } \\
\text { bevonható } \\
\text { tevékenységek } \\
\text { körét }\end{array}$ & $\begin{array}{l}\text { Témalista } \\
\text { tantárgyanként, } \\
\text { személyes szakmai } \\
\text { kapcsolatok, } \\
\text { tapasztalatok, } \\
\text { feljegyzések }\end{array}$ \\
\hline $\begin{array}{l}\text { A vállalati képzési } \\
\text { program elkészítése }\end{array}$ & $\begin{array}{l}\text { Támogatja a } \\
\text { vállalati képzési } \\
\text { program készítését }\end{array}$ & $\begin{array}{l}\text { Elkészíti a vállalati } \\
\text { képzési programot }\end{array}$ & $\begin{array}{l}\text { Dokumentum: } \\
\text { vállalati képzési } \\
\text { program }\end{array}$ \\
\hline $\begin{array}{l}\text { Az akadémiai és a } \\
\text { gyakorlati képzés } \\
\text { kapcsolatának } \\
\text { dokumentálása }\end{array}$ & $\begin{array}{l}\text { Feljegyzi a } \\
\text { tantárgyakoz kapcs. } \\
\text { gyak. tev. }\end{array}$ & - & $\begin{array}{l}\text { Dokumentumok: } \\
\text { tantárgyanként és } \\
\text { vállalatonként a } \\
\text { kapcsolódó gyak. } \\
\text { tev. listája }\end{array}$ \\
\hline
\end{tabular}

1. ábra. A vállalati képzési program elkészitésének folyamata 


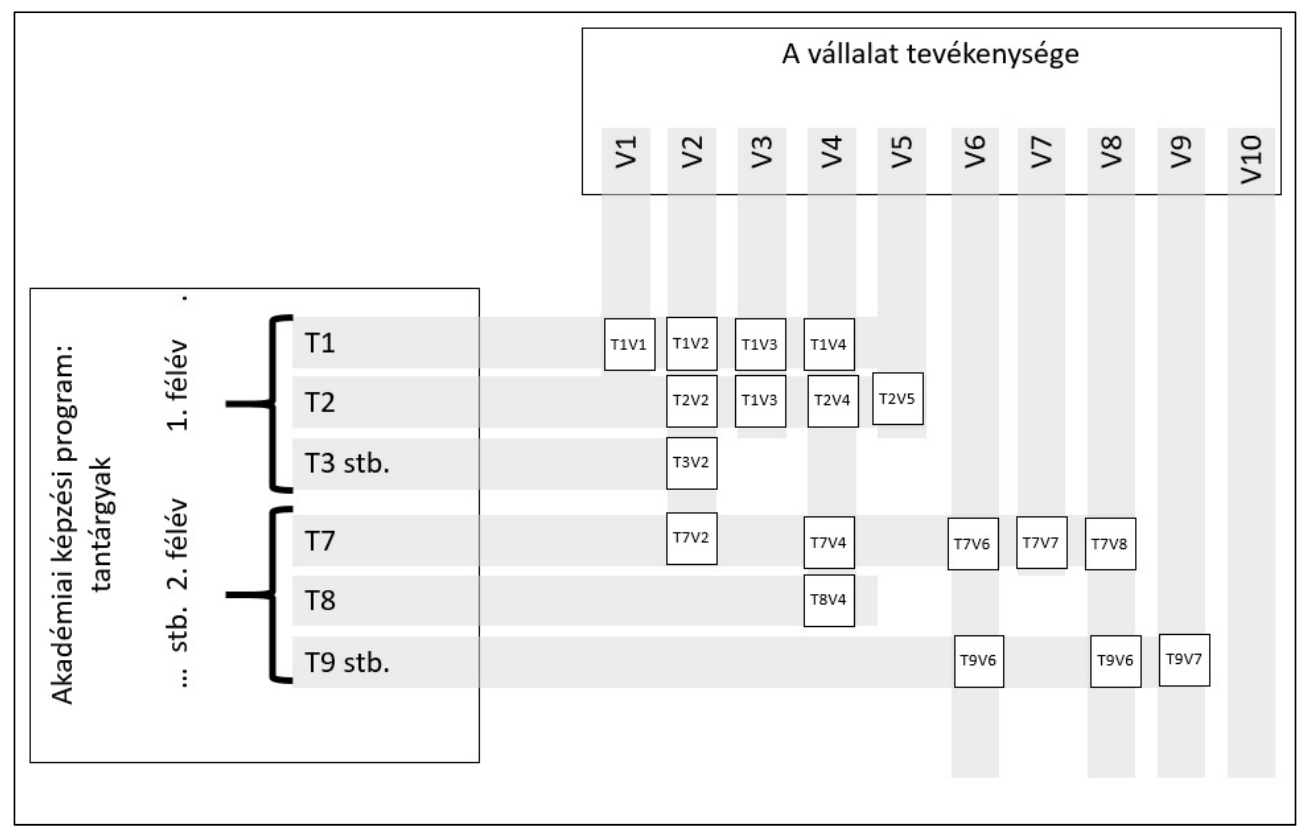

2. ábra. A vállalati tevékenységek és a tantárgyak szakmai tartalma közötti közös részek megtalálása kulcsfontosságú lépés volt a képzési program kifejlesztésében. Egy tevékenység több tantárgyhoz is kapcsolható, és egy tantárgy számos tevékenységhez köthetö. A T1V1 jelentése: a T1 tantárgy és a V1 vállalati tevékenység közös része.

Vállalati képzési program az 1. félév utáni gyakorlatra

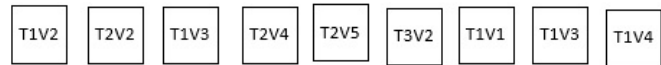

Vállalati képzési program az 2. félév utáni gyakorlatra
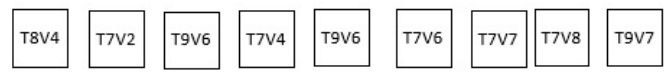

... így tovább minden félévre

3. ábra. Az 1. ábra szerint megtalált tevékenységek megfelelö idörendben elhelyezve adják a vállalati gyakorlati képzési programot.

A föiskola és a vállalat szakemberei hosszas egyeztetéseket folytattak arról, hogy mely vállalati tevékenységek építhetők be a duális képzésbe, és azok mely félév gyakorlatának legyenek részei. Ez az egyeztetés volt a vállalati gyakorlati képzési programok kulcslépése, mely két fázisra oszlott (2. és 3. ábra):

- meg kellett találni a tantárgyak (T) és a vállalati tevékenységek (V) szakmai tartalmi közös részeit;

- ki kellett alakítani a megfelelő időrendet. 
Egy vállalati tevékenységhez több tantárgy anyaga is kapcsolódhat. Ekkor tekintettel kell lenni az akadémiai képzés tantárgyainak időbeli elhelyezkedésére.

\subsection{Az oktatás feltételeinek kialakítá- sa a vállalatnál}

Még a legsikeresebb vállalat életében is komoly átgondolást igényel egy hallgató befogadása és képzése. A vállalatoknál általában vannak belső oktatások vagy külső partnerrel megvalósított továbbképzések, de nincsenek berendezkedve egy felsőfokú képzés megvalósítására. A vállalatnak a képzés teljes ideje alatt gondoskodnia kell a hallgatóról, és ez lényegesen különbözik a munkatársak időszakos továbbképzéseitől. Az alábbi fő szempontokat kell figyelembe vennie a vállalatnak:

- a hallgató jogilag ugyan már nagykorú, de még nincs felkészülve a munkavégzésre, ezért gondot kell fordítani a biztonságára, munkavédelmi, balesetvédelmi felkészítésére, önállóan nem tevékenykedhet az üzemben;

- a hallgató nem munkavállaló, ezért speciális helyzetben van a cégen belül, feladatait a gyakorlati képzési program határozza meg;

- a hallgatónak tanulnia kell, ezért a vállalati gyakorlat ideje alatt mindig kell hogy legyen mellette olyan mentor, aki a szakmai fejlődését segíti, lényegében tanítja;

- a hallgató előrehaladását a humáneröforrásért felelös részlegnek is figyelemmel kell kísérnie, ebbe a felsőoktatási intézménnyel való folyamatos kapcsolattartás is beleértendő.

A vállalat részéröl ez komoly munkaerő- és feladatátcsoportosításokat jelenthet. Mindenképpen igaz, hogy a vállalat részéről a duális képzésbe történő befektetésnek csak kisebb részét jelentik a hallgató számára nyújtandó dologi juttatások, a nagyobb áldozat, amit meg kell hozniuk, az alkalmazottaik munkaerejének részleges lekötése a gyakorlati program megvalósításának érdekében. A tapasztalat azt mutatja, hogy a legtöbb vállalat ezzel a ténnyel csak a képzés elindításának fázisában szembesül.

Azon vállalatok közül, amelyek elvben jónak és fontosnak tartják a duális képzést, nem biztos, hogy mindenki felvállalja ezt az áldozatot. A Nyíregyházi Főiskolával kezdetben szerződést kötött 9 vállalat közül 1 partner volt, aki emiatt visszalépett a duális képzéstől. A többi cég ezt felvállalta, de közös munkánk során elmondták, milyen komoly feladatokat jelent ez nekik.

\section{Következtetések}

A Nyíregyházi Főiskola 2015 szeptemberében indította első duális képzési programját a gépészmérnök szakon. Ez a beszámoló a duális képzési program kidolgozásának tapasztalatait foglalja össze.

Megerösítjük azt a tapasztalatot, hogy a duális képzésnek már az előkészítési szakaszában igen fontos az alapos egyeztetés a felsőoktatási intézmény és partnervállalata(i) között. Különösen érvényes ez a gyakorlati képzési program kidolgozására, azok tartalmi, időbeli és humánerőforrásszükséglet szerinti megtervezése.

\section{Köszönetnyilvánítás}

Ennek a publikációnak az elkészítését és megjelenését a TÁMOP-4.1.1.F-14/1/KONV2015-0007 „NYÍR-DUÁL”- A felsőoktatás területi, társadalmi, gazdasági szerepének fejlesztése Kelet-Magyarországon címü pályázati projekt támogatta.

\section{Szakirodalmi hivatkozások}

[1] Duális Képzési Tanács: A duális képzés alapelvei.

http://www.dualisdiploma.hu/documents/dual is-felsofoku-kepzes-alapelvei-a-dkt-

meghatarozasaban.pdf

(letöltés: 2016. január 8.)

[2] Battersea Tanácsadó, Szolgáltató Kft: Kutatás-fejlesztési tevékenység megvalósitása jó gyakorlatként azonositott magyarországi és külföldi duális képzési programok elemzése és a kutatáshoz kapcsolódó fejlesztések kapcsán, kutatási tanulmány, 2014. http://www.dualisdiploma.hu/documents/kuta tas-fejlesztesi-tevekenyseg-megvalositasa-jogyakorlatkent-azonositott-magyarorszagi-eskulfoldi-dualis-kepzesi-programok-elemzesees-a-kutatashoz-kapcsolodo-fejlesztesekkapcsan-zarotanulmany-educatio.pdf (letöltés: 2015. január 8.)

[3] www.dualisdiploma.hu

[4] www.nyf.hu/nyirdual 